\title{
EFEKTIVITAS MANAJEMEN PRAKTIK KERJA INDUSTRI DI SEKOLAH MENENGAH KEJURUAN KOTA YOGYAKARTA
}

\author{
Putut Said Permana, Sukoco \\ Universitas Pamulang, Universitas Negeri Yogyakarta \\ pututsaid@gmail.com, sukocogd@yahoo.com
}

\begin{abstract}
Abstrak
Penelitian ini bertujuan: (1) mengevaluasi keefektifan manajemen praktik kerja industri di SMK, (2) menganalisis kendala yang ada pada manajemen praktik kerja industri di SMK. Penelitian ini merupakan penelitian evaluasi dengan pendekatan kuantitatif. Teknik pengumpulan data menggunakan angket. Analisis data menggunakan teknik persentase. Hasil penelitian ini menunjukkan bahwa aspek perencanaan pada manajemen praktik kerja industri (prakerin) memiliki kriteria sangat efektif. Aspek pelaksanaan pada manajemen prakerin memiliki kriteria sangat efektif. Aspek evaluasi pada manajemen prakerin memiliki kriteria sangat efektif. Secara keseluruhan efektivitas manajemen prakerin di SMK Kota Yogyakarta memiliki kriteria sangat efektif. Analisis kendala pada penelitian ini menunjukkan bahwa pada aspek perencanaan dan pelaksanaan terdapat poin yang memiliki kesenjangan tinggi, yaitu: (1) pengurus pokja prakerin di sekolah berjumlah kurang dari empat orang, (2) dunia usaha dan dunia industry (DU/DI) yang berada di sekitar sekolah tidak selalu relevan dengan program keahlian di sekolah, (3) masih ada siswa yang mencari tempat prakerin sendiri, (4) relevansi program keahlian guru pembimbing dengan siswa yang dibimbing kurang diperhatikan, (5) pelaksanaan pembekalaan masih sering terkendala kedisiplinan siswa, (6) kelompok kerja (pokja) masih menemukan peserta prakerin yang menyelesaikan kegiatan prakerinnya tidak sesuai alokasi waktu.
\end{abstract}

Kata kunci: efektivitas, manajemen, praktik kerja industri

\section{EFFECTIVENESS OF THE WORK-BASED LEARNING MANAGEMENT IN VOCATIONAL HIGH SCHOOLS IN YOGYAKARTA MUNICIPALITY}

\author{
Putut Said Permana, Sukoco \\ Universitas Pamulang, Universitas Negeri Yogyakarta \\ pututsaid@gmail.com, sukocogd@yahoo.com
}

\begin{abstract}
This research aims to: (1) evaluate the effectiveness of the work-based learning (WBL) management in vocational high schools, and (2) analyze the existing constraints on the workbased learning (WBL) management in vocational high school. This study is an evaluation using a quantitative approach. The technique of collecting data using questionnaires. Data analysis using percentage technique. The results show that the aspects of the planning on the WBL management has a very effective criteria. On the implementation aspects, WBL management has very effective criteria. On the evaluation aspecs, WBL management has a very effective criteria. Overall, the effectiveness of WBL management in vocational high school in Yogyakarta Municipality has a very effective criteria. The constraints analysis in this study indicates that the aspects of the planning and implementation have points that have high discrepancy. Those points are: (1) member of the working group at the school less than four people, (2) industries/companies around the school is not always relevant with skills program at school, (3) there are students who are still looking for WBL place on their own, (4) relevance of teachers and students skills program did not affect the selection of WBL tutor, (5) preparatory program implementation is still often constrained with students discipline, and (6) working group still finds WBL participants who completed their activities not in accordance with the allocation of time.
\end{abstract}

Keywoords: constraints analysis, management, work-based learning 


\section{Pendahuluan}

Berkenaan dengan era perdagangan bebas Asia-Pasific Economic Cooperation (APEC) yang akan mulai masuk ke Indonesia pada tahun 2020, persaingan pada dunia usaha dan dunia industri (DUDI) pun akan meningkat. Oleh karenanya, dunia industri di Indonesia dituntut untuk meningkatkan kualitas sumber daya manusia (SDM) yang dimilikinya. Salah satu cara untuk meningkatkan kualitas SDM adalah dengan meningkatkan kualitas pendidikan. Menanggapi tantangan APEC tersebut maka pendidikan kejuruan dinilai menjadi salah satu solusi dalam meningkatkan kualitas SDM di Indonesia. Clarke \& Winch (2007, p.135) menyatakan bahwa "The proper aim of vocational education is to provide individuals with the skill to earn their living, thus supplying one of the conditions for economic prosperity." Tujuan yang tepat dari pendidikan kejuruan adalah menyiapkan seseorang dengan keterampilan untuk mendapatkan penghasilan dalam hidupnya sehingga dapat membantu untuk memiliki tingkat ekonomi yang memadai. Sejalan dengan itu, Gasskov (2000, p.5) menyatakan bahwa "The mandate of vocational education and training is manifold. First, the vocational education and training system should deliver both foundation and specialist skills to private individual, enabling them to find employment or launch their own business, to work productively and adapt to different technologies, task and conditions ..." Pernyataan tersebut memiliki makna bahwa pendidikan kejuruan dituntut untuk dapat memberikan keahlian dasar maupun spesialis bagi individu yang memungkinkan mereka untuk mencari pekerjaan atau memulai usaha mereka sendiri, dan juga untuk bekerja secara produktif dan mampu beradaptasi dengan perubahan atau perkembangan teknologi, tugas dan kondisi dalam dunia kerja. Dapat dikatakan bahwa orientasi utama pendidikan kejuruan adalah untuk mempersiapkan sumber daya manusia yang siap kerja dan menghasilkan individu yang ahli dalam berbagai bidang.

Pendidikan kejuruan memberikan kesempatan kepada individu untuk mem- persiapkan masa depannya dengan lebih optimal. Terkait dengan keuntungan dari pendidikan kejuruan bagi siswa, Hoeckel (2008, p.10) menyatakan bahwa "...individuals enjoy benefits from improved earnings, employment chances, mobility, capacity for lifelong learning, measures of working conditions and job satisfaction...". Pernyataan tersebut menjelaskan bahwa pendidikan kejuruan sangat menguntungkan bagi indivi$\mathrm{du}$ yang ingin mengasah keahlian dan kompetensi diri dalam menghadapi dunia kerja. Pendidikan kejuruan membekali individu dengan pengalaman kerja serta menjalani program yang mampu mengembangkan potensi diri dan keterampilan dasar serta pemahaman yang mengarah pada dunia kerja.

Di Indonesia, satuan pendidikan yang menyelenggarakan pendidikan kejuruan adalah sekolah menengah kejuruan (SMK). Misi utama SMK adalah untuk mempersiapkan peserta didik sebagai calon tenaga kerja yang memiliki kesiapan untuk memasuki DUDI. Keberadaan SMK dituntut untuk memenuhi kebutuhan masyarakat, yaitu kebutuhan tenaga kerja. Oleh karena itu peserta didik dituntut untuk memiliki keterampilan serta sikap professional dalam bidangnya. Namun pada kenyataannya keberadaan SMK dalam mempersiapkan tenaga kerja tingkat menengah yang terampil masih perlu ditingkatkan. Belum semua lulusan SMK dapat memenuhi tuntutan lapangan kerja sesuai dengan spesialisasinya. Badan Pusat Statistik (BPS) mencatat lulusan pendidikan SMK menempati urutan keempat tertinggi dalam persentase tingkat pengangguran terbuka (TPT) pada Februari 2015. Badan Pusat Statistik (BPS) merilis jumlah pengangguran pada Februari 2015 sebanyak 7,4 juta orang. Sekitar $15,8 \%$ dari total tersebut atau sekitar 1,1 juta orang lebih, merupakan lulusan Sekolah Menengah Kejuruan (SMK)(BPS, 2015).

Tabel 1 yang memuat data pengangguran terbuka menurut pendidikan tertinggi menunjukkan bahwa peningkatan jumlah pengangguran tamatan SMK pada interval waktu antara Februari 2014 hingga 
Februari 2015 adalah yang tertinggi dibandingkan dengan kategori pendidikan tertinggi lainnya. Hal tersebut sangat memprihatinkan mengingat tujuan SMK salah satunya adalah untuk mencetak sumber daya manusia yang siap kerja.

Tabel 1. Data BPS Jumlah Pengangguran Terbuka Menurut Pendidikan Tertinggi

\begin{tabular}{lcc}
\hline Tingkat & 2014 & 2015 \\
Pendidikan & Februari & Februari \\
\hline Tidak Sekolah & 134,040 & 124,303 \\
Tidak Tamat SD & 610,574 & 603,194 \\
SD & $1,374,822$ & $1,320,392$ \\
SMP & $1,693,203$ & $1,650,387$ \\
SMA & $1,893,509$ & $1,762,411$ \\
SMK & 847,365 & $1,174,366$ \\
Diploma & 195,258 & 254,312 \\
Universitas & 398,298 & 565,402 \\
Total & $7,147,069$ & $7,454,767$ \\
\hline
\end{tabular}

Aspek yang perlu diperhatikan terkait fakta tersebut salah satunya adalah bagaimana siswa di sekolah diberikan pelayanan pendidikan semaksimal mungkin terutama pada pelajaran praktik. Siswa dalam usahanya untuk meningkatkan keahlian perlu dukungan dari sekolah terkait fasilitas pendidikan. Namun pada kenyataannya masih banyak SMK yang belum memenuhi fasilitas pendidikan yang dibutuhkan. Di Kota Yogyakarta terdapat 32 SMK baik negeri maupun swasta. Menurut data yang dihimpun oleh Dinas Pendidikan Kota Yogyakarta, fasilitas praktik siswa SMK seperti bengkel dan ruang praktik masih terbatas. Masih ada beberapa SMK yang tidak memiliki bengkel dan ruang praktik, sementara tujuan SMK sendiri adalah melatih siswa terbiasa bekerja. Berikut adalah data fasilitas SMK Se-Kota Yogyakarta yang diambil pada tahun ajaran 2013/2014.

Data pada Tabel 2 dapat menjadi indikasi bahwa sekolah masih belum optimal dalam menghadirkan suasana belajar yang sesuai dengan tuntutan DUDI. Padahal hal tersebut sangat diperlukan siswa untuk lebih mengenal suasana kerja yang nanti akan dihadapinya. Keadaan tersebut dapat menjadi lebih buruk apabila alat-alat prak- tik di sekolah juga tidak dalam kondisi layak pakai. Oleh karenanya sekolah sangat dituntut untuk mampu menyediakan fasilitas yang relevan, agar kekhawatiran terkait kompetensi siswa dapat diminimalisir. Fasilitas praktik selain alat praktik yang harus diberikan oleh SMK kepada siswa adalah kegiatan praktik kerja industri (prakerin). Terkait dengan mutu lulusan dikhawatirkan SMK belum optimal dalam mengelola prakerin, sehingga lulusannya kurang memiliki kesiapan kerja. Prakerin dilaksanakan guna memberikan pengalaman kerja nyata bagi siswa. Materi yang digunakan pun disesuaikan dengan kebutuhan siswa. Jika pembelajaran praktik di sekolah masih belum mampu memenuhi kebutuhan siswa, maka dengan prakerin diharapkan kekurangan tersebut dapat terpenuhi.

Tabel 2. Jumlah Sekolah dan Fasilitas Praktik Di SMK Kota Yogyakarta

\begin{tabular}{clccc}
\hline No & Kecamatan & $\begin{array}{c}\text { Jumlah } \\
\text { Sekolah }\end{array}$ & Bengkel & $\begin{array}{c}\text { Ruang } \\
\text { Praktik }\end{array}$ \\
\hline 1 & Mantrijeron & 3 & 0 & 2 \\
2 & Wirobrajan & 1 & 0 & 0 \\
3 & Kraton & 1 & 0 & 1 \\
4 & Mergangsan & 3 & 6 & 7 \\
5 & Umbulharjo & 11 & 2 & 75 \\
6 & Gondomanan & 1 & 0 & 0 \\
7 & Gedongtengen & 1 & 0 & 0 \\
8 & Danurejan & 1 & 0 & 0 \\
9 & Gondokusuman & 4 & 10 & 16 \\
10 & Jetis & 4 & 4 & 30 \\
11 & Tegalrejo & 2 & 1 & 1 \\
& $\quad$ Jumlah & 32 & 23 & 132 \\
\hline
\end{tabular}

Ellis (2003, p.2) mengatakan bahwa "Work-based learning is defined as a coherent sequence of job training and work experience that involves actual work experience and connects classroom learning to work activities." Pernyataan tersebut memiliki arti bahwa prakerin merupakan perpaduan persiapan yang dilakukan di sekolah (berbasis sekolah) dan melalui pengalaman kerja di dunia nyata, yang didesain agar siswa memperoleh pengetahuan, ketrampilan dan sikap untuk kepentingan karir dalam setting kerja yang nyata. Prakerin memberikan sekaligus mengajarkan kepada siswa akan bagaimana kehidupan di dunia kerja, disamping menjadi tempat uji coba ilmu 
yang dipelajari di sekolah. Siswa dapat mengetahui keterkaitan antara pembelajaran di sekolah dengan apa yang dibutuhkan dalam dunia kerja nyata. Mereka dapat memahami urgensi dari pengembangan diri sehingga mampu mengambil keputusan terbaik untuk masa depannya. Sejalan dengan itu, Holzer \& Lerman (2014, p.3) terkait dengan keunggulan prakerin mengatakan bahwa "Work-based learning has a number of advantages over other educational or training programs. Perhaps the most important is that students do not have to choose between enhancing their educational credentials or their work experience; with work-based learning they can improve both." Siswa diberikan pengalaman yang jarang mereka dapatkan dalam pembelajaran di sekolah melalui prakerin. Siswa pada kegiatan prakerin diharapkan mampu memahami tentang bagaimana tata dan aturan di dunia industri/usaha, mampu mengembangkan keterampilan-keterampilan berpikir, mampu mengamati dan mengambil keputusan yang tepat dalam penyelesaian masalah, sehingga ketika nanti siswa telah lulus, mereka sudah benar-benar siap bekerja baik secara keilmuan maupun secara mental.

Prakerin dalam pelaksanaannya dilakukan oleh sekolah bersama DUDI atau instansi lain yang berhubungan dengan DUDI sebagai institusi pasangan. Prakerin diselenggarakan secara bertahap mulai dari SMK yang dinilai telah memiliki kesiapan minimal untuk melaksanakan model pendidikan ini. Hal tersebut dilakukan mengingat beragamnya kondisi SMK dan dunia industri yang ada. Kriteria kesiapan tersebut ditentukan oleh keberhasilan SMK yang bersangkutan dalam membina hubungan kerja sama dengan dunia usaha/ industri (memiliki institusi pasangan), dan keberhasilan manajemen dalam mengelola kegiatan pendidikan dan kelembagaannya. Menurut Boud \& Solomon (2003, pp.4-7) pola atau model penyelenggaraan WBL secara garis besar memiliki enam karakteristik, yaitu (1) adanya kemitraan/hubungan antara institusi pendidikan dengan dunia usaha/industri, (2) siswa dilibatkan sebagai pekerja, (3) program dalam WBL dirancang dengan mengikuti apa yang dibutuhkan di tempat kerja, (4) titik awal (starting point) dan level pendidikan dalam program ditentukan setelah siswa dilibatkan dalam proses perumusan kompetensi, (5) elemen penting dalam WBL adalah proyek-proyek pembelajaran (learning project) yang akan dilakukan di tempat kerja, (6) institusi pendidikan menilai penilaian pembelajaran berdasarkan kesepakatan dalam program ini.

Prakerin pada dasarnya merupakan sistem yang membutuhkan manajemen supaya dapat berjalan sesuai dengan tujuan. Manajemen merupakan aktivitas yang di dalamnya terdapat perencanaan, pengorganisasian, dan pengontrolan. Dasar dari manajemen adalah untuk mengatur dan menyelesaikan sesuatu melalui individu, kelompok atau organisasi. Certo \& Certo (2012, pp.7-8) mengatakan "management is the process of reaching organizational goals by working with and through people and other organizational resources." Di SMK prakerin dikelola oleh kelompok kerja (pokja). Tujuan dari pengelolaan prakerin oleh pokja di sekolah adalah untuk mengarahkan, membantu, dan memberi informasi kepada siswa tentang pelaksanaan prakerin. Siswa dapat mengembangkan keahliannya pada saat melaksanakan prakerin. Pemilihan waktu yang tepat dan wadah industri yang baik dapat menunjang pencapaian belajar siswa yang nantinya akan berpengaruh terhadap kualitas lulusan. Kesiapan siswa untuk menghadapi DUDI akan lebih optimal. Oleh karenanya manajemen prakerin di SMK sebaiknya lebih dioptimalkan.

Pelaksanaan prakerin pada kenyataannya bukan tanpa kendala. Sebagai contoh, Sukarnati $(2011$, p.89) dalam penelitiannya tentang pengembangan model manajemen prakerin menyebutkan beberapa kendala yang kerap terjadi pada pelaksanaan prakerin. Penelitian tersebut memiliki kesimpulan bahwa belum ada keterkaitan antara program di industri dengan program di sekolah, guru-guru belum mengaitkan bahan ajar di kelas dengan aplikasinya di industri. Selain itu, penyelenggara prakerin di 
SMK belum secara tepat memahami makna konsep prakerin dan konsep penerapannya. Hal-hal tersebut adalah kendala yang dapat terjadi pada setiap SMK. Sejalan dengan hal tersebut, Herlina (2013, p.i) dalam penelitiannya tentang efektivitas pengelolaan prakerin menyebutkan beberapa kendala yang ditemukannya, yaitu (1) pemahaman instruktur tentang Prakerin yang masih kurang, dan (2) belum adanya pelatihan bagi guru pembimbing melalui on the job training (OJT).

Melihat kenyataan dan kendala yang terjadi maka dapat dikatakan bahwa keberhasilan SMK dalam melaksanakan prakerin secara dominan ditentukan oleh kehandalan manajemen prakerin yang bersangkutan. Oleh karenanya manajemen prakerin, dapat menjadi alternatif strategis untuk meningkatkan kualitas pendidikan kejuruan. Perbaikan kualitas manajemen dirasa mampu mengatasi kendala-kendala yang selama ini ada pada implementasi prakerin di SMK.

Pengamatan terhadap manajemen prakerin di SMK kaitannya dengan fasilitas pendidikan yang diberikan sekolah merupakan elemen penting dalam memberikan pandangan yang nantinya mungkin berguna sebagai bahan pertimbangan dalam meningkatkan mutu dan kinerja sekolah. Guna mengetahui faktor-faktor apa yang selama ini menyebabkan kurang optimalnya manajemen prakerin di SMK maka evaluasi perlu untuk dilakukan.

Berdasarkan uraian tersebut, penelitian ini bertujuan untuk: (1) mengevaluasi keefektifan manajemen praktik kerja industri di SMK, (2) menganalisis kendala yang ada pada manajemen praktik kerja industri di SMK

\section{Metode Penelitian}

Penelitian ini merupakan penelitian evaluasi yang menggunakan jenis evaluasi program dengan pendekatan kuantitatif. Model yang digunakan dalam penelitian ini adalah model pengambilan keputusan yang dikembangkan oleh Malcolm Provus yang dikenal dengan Discrepancy Model.
Model evaluasi ini menekankan pada pandangan adanya kesenjangan antara tujuan yang diharapkan dengan hasil yang dicapai dalam pelaksanaan program.

Tempat penelitian ini adalah SMK di wilayah kota Yogyakarta. Sasaran penelitian ini adalah kelompok kerja (pokja) yang ditugaskan untuk mengelola prakerin. Waktu untuk penelitian ini terbagi menjadi dua yaitu pertama waktu untuk studi pendahuluan, kedua waktu penelitian. Studi pendahuluan dilakukan pada April 2015 Mei 2015, sementara penelitian dilakukan selama bulan Mei 2015-Juni 2015.

Populasi dalam penelitian ini adalah anggota kelompok kerja (pokja) manajemen prakerin dari 18 SMK di Kota Yogyakarta yang berjumlah 88 orang. Dalam penelitian ini sampel diambil dengan teknik sampling jenuh dikarenakan penelitian ini merupakan penelitian populasi. "Sampling jenuh adalah teknik penentuan sampel bila semua anggota populasi digunakan sebagai sampel." (Sugiyono, 2014, p.156).

Data penelitian ini berupa data kuantitatif. Teknik pengumpulan data menggunakan angket. Instrumen penelitian berupa angket tertutup. Angket yang digunakan adalah angket dengan skala Guttman, ditujukan kepada anggota pokja prakerin di setiap SMK.

Dalam penelitian ini data yang diperoleh dianalisis dengan teknik persentase. Adapun langkah-langkah dalam memberikan nilai dilakukan dengan cara sebagai berikut. Pertama memberikan penilaian terhadap setiap ketercapaian indikator pelaksanaan program dengan memberikan skor 1 (satu) untuk setiap skor yang dilaksanakan, skor 0 (nol) untuk indikator pelaksanaan program yang tidak dilaksanakan.

Selanjutnya menghitung persentase ketercapaian dengan menjumlahkan kinerja yang dilaksanakan, kemudian dibagi dengan jumlah seluruh kriteria pelaksanaan program sesuai dengan standarnya, kemudian dikalikan 100. Guna mengetahui data hasil konversi kuantitatif ke kualitatif digunakan kriteria kuantitatif tanpa pertimbangan dari Arikunto \& Jabar (2014, p.35) seperti pada Tabel 3 berikut. 
Tabel 3. Kriteria Kuantitatif tanpa Pertimbangan

\begin{tabular}{cc}
\hline Interval Skor & Data Kualitatif \\
\hline $81 \%-100 \%$ & Sangat Efektif \\
$61 \%-80 \%$ & Efektif \\
$41 \%-60 \%$ & Cukup \\
$21 \%-40 \%$ & Kurang \\
$<21 \%$ & Sangat Kurang \\
\hline
\end{tabular}

\section{Hasil Penelitian dan Pembahasan}

Hasil penelitian mencakup komponen yang berkaitan dengan efektivitas manajemen prakerin di SMK Kota Yogyakarta. Komponen tersebut adalah perencanaan, pelaksanaan, dan evaluasi.

Data hasil penelitian pada aspek perencanaan menunjukkan bahwa ketercapaian perencanaan manajemen prakerin di SMK Kota Yogyakarta mencapai rata-rata $81 \%$ dengan rata-rata kesenjangan 19\%. Skor yang dicapai ini menunjukkan bahwa secara umum efektivitas perencanaan manajemen prakerin di SMK Kota Yogyakarta tercapai dengan kriteria "Sangat Efektif".

Suatu organisasi membutuhkan pengembangan dalam usahanya untuk meningkatkan kinerja guna mencapai tujuannya. Harapan untuk mendapatkan hasil yang efektif dan maksimal pada proses pengembangan akan dapat tercapai apabila sebelumnya telah merancang suatu strategi yang matang. Oleh karenanya diperlukan suatu tuntunan, agar pada pelaksanaannya strategi yang dirancang tidak keluar dari tujuan utama organisasi. Sejalan dengan itu, dalam mengelola kegiatan prakerin, pokja perlu menyusun suatu perencanaan yang baik. Perencanaan sendiri merupakan aspek yang tidak dapat diabaikan dalam manajemen. Secara khusus mengenai perencanaan pendidikan, Coombs (1970, p.14) berpandangan bahwa "Educational planning, in its broadest generic sense, is the application of rational, systematic analysis to the process of educational development with the aim of making education more effective and efficient in responding to the needs and goals of its students and society". Intinya adalah perencanaan pendidikan merupakan penerapan rasionalitas serta analisis sistem pada proses pengembangan pendidikan dengan tujuan membuat pendidikan lebih efektif dan efisien. Melalui pandangan tersebut dapat disimpulkan bahwa beberapa pertimbangan diperlukan guna menyusun perencanaan pendidikan yang lebih baik.

Hasil analisis kendala menemukan bahwa pada aspek perencanaan terdapat butir pernyataan yang memiliki kesenjangan cukup tinggi. Kriteria kesenjangan yang cukup tinggi ditentukan dengan melihat butir pernyataan yang memiliki kriteria capaian dibawah "Cukup". Butir-butir pernyataan tersebut adalah sebagaimana yang dipaparkan pada Gambar 1 berikut:

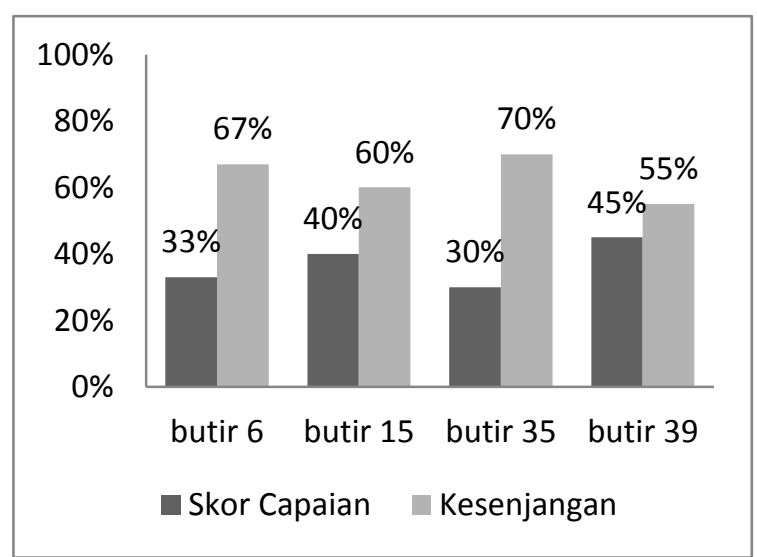

Gambar 1. Butir Kendala Pada Aspek Perencanaan

Kesenjangan pertama (butir 6) terkait dengan pengurus pokja prakerin yang berjumlah kurang dari empat orang. Suatu lembaga atau organisasi membutuhkan pengurus agar dapat berjalan sesuai tujuan. Begitu pula dengan pokja prakerin. Idealnya, pokja prakerin minimal memiliki perangkat-perangkat inti antara lain ketua, sekretaris, bendahara, dan koordinator masing-masing program keahlian. Hal tersebut bertujuan agar pekerjaan pokja dalam mengelola prakerin lebih efektif dan efisien. Kurangnya jumlah guru yang berpengalaman dalam bidang prakerin bisa jadi menjadi faktor yang menyebabkan hal tersebut terjadi. Pengelola prakerin yang dalam hal ini adalah pokja idealnya merupakan seseorang yang memiliki pengetahuan terkait kegiatan prakerin atau memiliki pengalaman langsung mengenai dunia industri. Hal tersebut dikarenakan dalam 
menyusun kegiatan prakerin, pokja diharapkan mampu menerapkan link and match antara sekolah dengan DUDI.

Faktor lain yang mungkin dapat menyebabkan kendala itu terjadi adalah adanya asumsi dari penanggung jawab prakerin (baik Kepala Sekolah maupun yang ditunjuk olehnya) bahwa kegiatan prakerin mampu dikelola oleh satu atau dua pengurus saja. Penanggung jawab prakerin merasa tugas guru yang ada sudah cukup banyak, sehingga tidak perlu menambah beban mereka dengan memberi tanggung jawab mengelola prakerin. Hal tersebut dapat dimengerti apabila jumlah guru yang ada di sekolah tersebut memang tidak banyak. Namun, apabila guru yang ada sudah mencukupi maka sudah seharusnya pengelolaan prakerin diberikan kepada pokja yang memadai. Tidak bisa dipungkiri bahwa kegiatan prakerin merupakan salah satu keunggulan SMK, maka dari itu dalam pengelolaannya membutuhkan sumber daya manusia yang kompeten dan memadai.

Selanjutnya pada kesenjangan kedua (butir 15) terkait dengan relevansi DUDI yang berada di sekitar SMK dengan program keahlian yang ada di SMK tersebut. Kebutuhan akan DUDI yang relevan dengan program keahlian siswa merupakan salah satu yang utama dalam pelaksanaan prakerin. Tanpa adanya DUDI yang relevan dengan program keahlian, maka siswa tidak dapat melaksanakan kegiatan prakerin. Sejalan dengan hal itu, Alfeld (2015, p.26) mengatakan "...The most effective WBL programs, research shows, have a clear link between what is learned in the classroom and what is learned on the job..." Program prakerin yang efektif memiliki hubungan yang jelas antara pembelajaran di kelas dan apa yang dipelajari di tempat kerja. Permasalahan relevansi antara DUDI yang ada di sekitar sekolah dengan program keahlian SMK tersebut dapat menjadi hambatan tersendiri bagi pokja dalam menentukan DUDI mitra. Apabila DUDI yang ada di sekitar sekolah sesuai dengan program keahlian mereka, maka pokja akan lebih mudah mendata calon tempat prakerin bagi siswa. Sekolah memang tidak me- miliki kuasa untuk menentukan lokasi DUDI yang ada di sekitarnya, namun ada baiknya jika hal ini diangkat agar mendapat perhatian dan kemudian dapat dicarikan solusinya.

Kesenjangan ketiga (butir 35) terjadi pada pernyataan yang mengatakan bahwa masih ada siswa yang mencari tempat prakerin sendiri. Hal tersebut memperlihatkan bahwa pokja prakerin di SMK Kota Yogyakarta belum sepenuhnya mampu memenuhi kebutuhan siswa terkait tempat prakerin. Hal ini dapat terjadi karena pengaruh dari kendala pada butir 15 yaitu DUDI yang berada di lingkungan sekolah belum relevan dengan program studi SMK tersebut. Kendala itu menyebabkan pokja kesulitan dalam mendata DUDI yang akan dijadikan mitra dalam kegiatan prakerin. Namun tentu saja alasan tersebut tidak berlaku bagi pokja yang benar-benar berkomitmen dalam menyediakan tempat prakerin siswa. Oleh karena itu dapat dikatakan bahwa permasalahan tempat prakerin ini terjadi akibat sikap dari pokja yang kurang profesional. Profesionalitas dari anggota pokja sendiri sangat dibutuhkan guna menyukseskan program prakerin secara keseluruhan, karena dengan adanya sikap profesional dari anggota pokja maka motivasi dalam mencapai tujuan umum pokja akan lebih meningkat. Sejalan dengan hal itu, Mardiningsih \& Djukri (2015, p.214) mengatakan "Pengembangan keprofesionalan guru akan diikuti oleh peningkatan efektifitas kegiatan belajar mengajar dan secara tidak langsung peningkatan keprofesionalan guru juga akan berdampak pada peningkatan mutu pendidikan secara luas".

Kesenjangan terakhir (butir 39) yang memiliki kensenjangan tinggi pada aspek perencanaan adalah terkait relevansi program keahlian antara guru pembimbing dengan siswa yang dibimbingnya. Hal tersebut mengindikasikan bahwa mayoritas pokja prakerin di SMK Kota Yogyakarta dalam menentukan guru pembimbing siswa tidak menghiraukan relevansi program keahlian antara kedua belah pihak. Fungsi relevansi program keahlian antara guru 
pembimbing dengan siswa peserta prakerin antara lain adalah efisiensi dan efektivitas. Apabila keahlian guru pembimbing relevan dengan program keahlian siswa maka diharapkan guru dapat lebih optimal dalam memberikan bimbingan. Guru tentunya lebih mengerti materi-materi yang sedang dipelajari oleh siswanya, dan pengalaman guru pun dapat menjadi butir lebih dari proses bimbingan tersebut. Guru pembimbing dalam melaksanakan tugasnya diharapkan memiliki pengetahuan yang luas serta keterampilan yang mumpuni. Mereka dituntut untuk memiliki pemahaman, pengetahuan yang baik tentang dunia usaha dan dunia industri, serta diharapkan bersungguh-sungguh dalam membagi pengalamannya kepada siswa peserta prakerin.

Melihat peran dari guru pembimbing yang dipaparkan di atas, maka relevansi ini dirasa penting khususnya bagi siswa peserta prakerin. Guru dapat memahami apa yang sedang dihadapi oleh siswanya sehingga jika nantinya terjadi permasalahan, guru pembimbing diharapkan dapat mengambil langkah tepat dan mencarikan solusinya. Siswa juga dapat berkonsuktasi terkait materi yang mereka dapatkan saat prakerin. Hal ini sebagai antisipasi apabila pembimbing lapangan dari DUDI tidak melaksanakan tugasnya dengan optimal, karena tidak jarang peserta prakerin dibiarkan dan dilepas begitu saja tanpa diberikan pemahaman yang lebih mendalam terkait tugas yang harus mereka kerjakan. Kendala terkait relevansi bidang antara guru pembimbing dengan siswa dapat terjadi karena keterbatasan guru di sekolah tersebut. Direktur Direktorat Pembinaan Sekolah Menengah Kejuruan (2008, p.8) menyatakan bahwa "Pembimbing terdiri dari pembimbing internal yaitu guru produktif yang bertanggung jawab terhadap pembelajaran kompetensi, dan pembimbing eksternal yaitu staf dari Dunia Kerja yang sekaligus bertindak selaku instruktur pembimbing yang mengarahkan peserta didik dalam melakukan pekerjaannya."

Dari pernyataan tersebut maka dapat diasumsikan bahwa jumlah guru di suatu SMK sangat berpengaruh terhadap kelan- caran pelaksanaan kegiatan prakerin. Anggota pokja terdiri atas guru-guru dan apabila pembimbing peserta prakerin juga diambil dari guru maka dapat dibayangkan apa yang terjadi dengan sekolah yang kekurangan guru. Hal tersebut dapat memaksa pokja untuk menentukan guru pembimbing prakerin hanya dari guru yang tersedia saat itu saja, sehingga belum tentu memiliki bidang yang sama dengan siswa yang dibimbing.

Data hasil penelitian selanjutnya terkait dengan aspek pelaksanaan. Bagaimanapun hebatnya suatu perencanaan akan menjadi sia-sia jika tidak dilaksanakan. Zomorrodian (2011, p.1125) mengatakan "The most formidable part of strategic planning that has to do with the implementation. This is a phase that everything that has been planned for needs to be put into action ...". Hal yang sama berlaku pula pada manajemen prakerin. Beberapa tahapan dalam hal ini dilakukan oleh pokja prakerin guna melaksanakan kegiatan prakerin. Tahapan tersebut sesuai dengan program kerja yang disusun oleh pokja pada masing-masing sekolah. Berdasarkan data hasil penelitian tersebut menunjukkan bahwa pelaksanaan manajemen prakerin di SMK Kota Yogyakarta mencapai rata-rata $83 \%$ dengan rata-rata kesenjangan sebesar $17 \%$. Skor yang dicapai ini menunjukkan bahwa secara umum efektivitas pelaksanaan manajemen prakerin di SMK Kota Yogyakarta tercapai dengan kriteria "Sangat Efektif".

Melihat pentingnya proses pelaksanaan pada suatu kegiatan maka dapat disimpulkan bahwa kualitas pelaksanaan akan berpengaruh pada kualitas output dari kegiatan tersebut. Keberhasilan kegiatan prakerin dalam hal ini merupakan tujuan dari manajemen prakerin di setiap SMK. Tidak hanya berhasil melaksanakan, namun juga bagaimana manajemen prakerin dapat membuat kegiatan prakerin tersebut menjadi efektif dan efisien bagi pesertanya. Sejalan dengan itu, Durlak (2011, p.2) mengatakan bahwa " Research clearly indicates that quality implementation is one critical factor associated with program outcomes ...". Melalui penelitian terkait peningkatan 
prestasi pada 200 siswa di suatu sekolah, lebih lanjut Durlak (2011, p.5) berpendapat bahwa "With poor implementation, you may get no or just a small amount of change; with effective/high quality implementation, you may get changes of larger magnitude." Dari penelitian itu dapat disimpulkan bahwa kualitas dari pelaksanaan dapat mempengaruhi outcomes dari suatu program. Pada akhirnya dapat dilihat keterkaitan antara keberhasilan pelaksanaan kegiatan prakerin dengan efektivitas manajemen prakerin secara keseluruhan di SMK.

Meskipun pada hasil penelitian menunjukkan aspek pelaksanaan memiliki persentase capaian $83 \%$, namun hal tersebut bukan berarti pelaksanaan pada manajemen prakerin tanpa kendala. Melalui kesenjangan sebesar $17 \%$ dapat diketahui pada hal apakah aspek pelaksanaan ini mengalami kendala. Diagram pada Gambar 2 berikut menyajikan butir dengan capaian kriteria kurang dari "Cukup" pada aspek pelaksanaan.

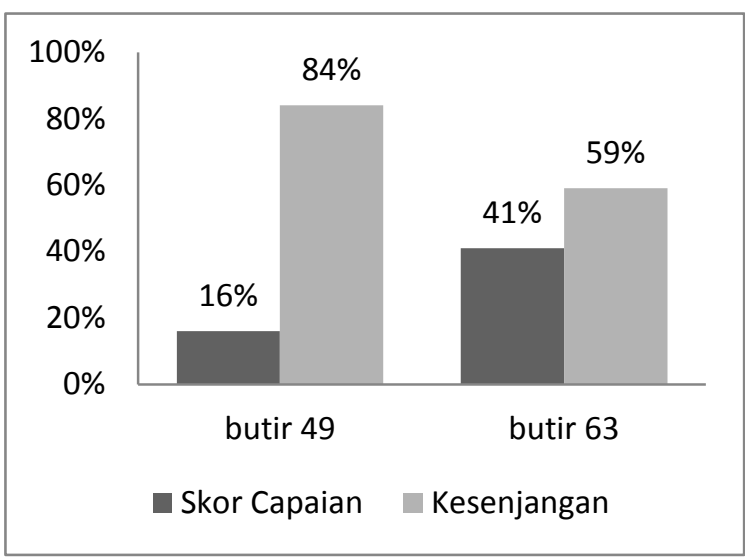

Gambar 2. Butir Kendala Pada Aspek Pelaksanaan

Kesenjangan pertama (butir 49) terkait dengan kedisiplinan siswa pada saat pembekalan. Pembekalan merupakan aktivitas wajib bagi peserta yang akan mengikuti kegiatan prakerin. Pada kegiatan pembekalan, peserta akan diberikan materi umum terkait apa yang nanti akan dihadapi di tempat kerja. Pembekalan dilaksanakan oleh pokja prakerin dengan materimateri yang telah disiapkan dalam bentuk buku panduan. Diharapkan dengan adanya pembekalan, siswa akan memiliki wawasan seputar fungsi dan tujuan prakerin serta memiliki kepercayaan diri dalam melaksanakan praktik di lapangan. Siswa membolos pada saat pembekalan bukan lagi menjadi sesuatu yang baru. Sangat disayangkan karena hal tersebut masih belum dapat diatasi dengan optimal. Melihat fungsi dari pembekalan maka pihak yang sebenarnya dirugikan adalah siswa itu sendiri. Informasi terkait prakerin yang sangat berguna akan menjadi sia-sia karena sikap acuh mereka.

Fenomena ini tentunya bukan tanpa sebab. Kemungkinan yang dapat menyebabkan ketidakdisiplinan siswa tadi bisa jadi terkait dengan cara pokja menyelenggarakan kegiatan pembekalan. Bisa jadi dari segi materi yang dari tahun ke tahun selalu berulang tanpa pengembangan. Siswa calon peserta prakerin tentu saja lebih memilih untuk bertanya kepada siswa yang telah melakukan prakerin daripada harus mengikuti kegiatan pembekalan. Penyebab lainnya mungkin saja ada pada cara penyajian materi. Siswa merasa kegiatan pembekalan terlalu membosankan untuk diikuti. Jika memang materi yang diberikan masih sama dengan tahun sebelumnya, paling tidak pokja dapat menyajikan materi dengan cara yang berbeda. Hal tersebut tentunya untuk menarik minat siswa dalam mengikuti pembekalan.

Kesenjangan terakhir (butir 63) pada aspek pelaksanaan ini terkait dengan masa praktik peserta prakerin. Ini menunjukkan bahwa masih banyak SMK di Kota Yogyakarta yang peserta prakerinnya tidak melaksanakan kegiatan prakerin sesuai waktu yang ditetapkan. Hal tersebut berpotensi menghasilkan permasalahan dalam pelaksanaan prakerin. Pokja menentukan waktu pelaksanaan prakerin tentunya telah melalui pertimbangan yang matang. Apabila pada pelaksanaannya masih ada peserta yang tidak disiplin, maka tentunya dapat merugikan semua pihak yang terkait dengan prakerin.

Kendala ini tidak sepenuhnya kesalahan siswa. Bisa jadi siswa tidak berniat melanggar waktu prakerin yang telah ditentukan. Misalnya, pada saat prakerin 
siswa mengalami musibah yang membuatnya tidak dapat melaksanakan tugas untuk beberapa waktu. Hal itu membuat siswa tersebut mengganti waktu yang ditinggalkannya agar pencapaian waktu prakerinnya sama dengan siswa lain. Otomatis keadaan seperti itu akan membuat siswa tersebut menyelesaikan kegiatan prakerinnya tidak sesuai waktu yang telah ditetapkan. Apabila hal seperti ini yang terjadi maka tidak ada yang perlu disalahkan. Namun, apabila kendala tersebut terjadi akibat kelalaian siswa, maka pokja perlu menindak tegas yang bersangkutan dan menentukan suatu kebijakan agar pada prakerin berikutnya hal yang serupa tidak terjadi. Kelalaian siswa yang dimaksudkan disini misalnya membolos. Siswa peserta prakerin yang kurang memiliki motivasi dalam kegiatan prakerin bisa saja membolos jika ada kesempatan. Apabila sikap siswa tersebut diketahui instruktur atau guru pembimbing maka ia harus mengganti waktu kerja di hari lain.

Selain motivasi dari siswa itu sendiri, faktor lain yang dapat mendorong siswa untuk membolos adalah sikap dari DUDI. Banyak DUDI yang beranggapan keberadaan peserta prakerin hanya akan menjadi beban. Padahal seharusnya sebagai mitra sekolah, DUDI berkewajiban untuk membimbing peserta prakerin sebagaimana yang telah disepakati dengan pihak sekolah sebelumnya. Siswa tidak diberi kesempatan untuk melakukan tugas yang sesuai bidangnya, sehingga mereka datang ke tempat kerja hanya untuk menonton kegiatan yang ada di sana. Melihat perlakuan tersebut bisa jadi siswa merasa malas dan kemudian membolos.

Aspek ketiga dalam penelitian ini adalah aspek evaluasi pada manajemen prakerin di SMK Kota Yogyakarta. Berdasarkan deskripsi data hasil penelitian menunjukkan bahwa ketercapaian evaluasi manajemen prakerin di SMK Kota Yogyakarta mencapai rata-rata $97 \%$ dengan ratarata kesenjangan sebesar 3\%. Skor yang dicapai ini menunjukkan bahwa secara umum efektivitas evaluasi manajemen prakerin di SMK Kota Yogyakarta tercapai dengan kriteria "Sangat Efektif". Evaluasi pada bidang pendidikan yang dalam hal ini adalah manajemen prakerin dilakukan guna mengetahui pencapaian pokja dalam mengelola kegiatan prakerin di SMK. Selain itu evaluasi pada manajemen prakerin juga diharapkan mampu menganalisis outcomes yang dihasilkan sehingga kemudian dapat memainkan peran vital dalam meningkatkan kualitas kegiatan prakerin selanjutnya. Fitzpatrick, Sanders, \& Worthen (2011, p.7) menyatakan "evaluation is determining the worth or merit of an evaluation object (whatever is evaluated). More boardly, we define evaluation as the identification, clarification, and application of defensible criteria to determine an evaluation object's value (worth or merit) in relation to those criteria." Pernyataan tersebut memberikan pemahaman bahwa fungsi utama evaluasi adalah memberi informasi yang valid dan dapat dipercaya mengenai kinerja kebijakan, yaitu seberapa jauh kebutuhan, nilai dan kesempatan yang telah dicapai melalui tindakan publik. Kemudian evaluasi juga memberi sumbangan pada klarifikasi dan kritik terhadap nilai-nilai yang mendasari pemilihan tujuan dan target, nilai diperjelas dengan mendefinisikan dan mengoperasikan tujuan dan target. Nilai juga dikritik dengan menanyakan secara sistematis kepantasan tujuan dan taget dalam hubungan dengan masalah yang dituju yang dapat menganalisis alternatif sumber nilai (misalnya kepentingan kelompok) maupun landasan mereka dalam berbagai bentuk rasionalitas (misalnya teknis, ekonomis, sosial, substantif). Sejalan dengan hal tersebut, Jahanian (2012, p.253) pada jurnal internasionalnya tentang evaluasi pendidikan mengatakan bahwa "Evaluation is a process in which an educational and training procedure is compared with its predetermined goals to find out their fulfillment."

Guna mencapai tujuan prakerin yang diinginkan, pokja perlu mengetahui kesesuaian antara prosedur yang dilakukan dengan yang telah dirancang. Hal tersebut memperlihatkan bagaimana pentingnya evaluasi dilakukan pada program atau kegiatan pendidikan. Intinya adalah dengan 
evaluasi pokja dapat mengetahui apa yang dapat dilakukan dan apa yang tidak dapat dilakukan untuk kemudian dianalisis sesuai kebutuhan guna pengembangan program di kemudian hari. Melihat pentingnya peran evaluasi tersebut maka dapat dikatakan bahwa keberhasilan evaluasi pada kegiatan prakerin akan mempengaruhi efektivitas manajemen prakerin di SMK.

Berdasarkan hasil pencapaian dari setiap aspek, dapat diketahui pencapaian efektivitas manajemen prakerin di SMK Kota Yogyakarta secara keseluruhan. Rekapitulasi hasil capaian dan kesenjangan pengelolaan prakerin oleh pokja secara umum dapat dilihat pada Tabel 4. Berdasarkan paparan Tabel 4 tersebut dapat diketahui bahwa kriteria manajemen prakerin di SMK Kota Yogyakarta adalah "Sangat Efektif".

Tabel 4. Hasil Rekapitulasi Data Rerata Persentase Aspek Manajemen Prakerin

\begin{tabular}{cccc}
\hline No & Aspek & Skor & Kesenjangan \\
\hline 1 & Perencanaan & $81 \%$ & $19 \%$ \\
2 & Pelaksanaan & $83 \%$ & $17 \%$ \\
3 & Evaluasi & $97 \%$ & $3 \%$ \\
Persentase Total & $87 \%$ & $13 \%$ \\
\hline
\end{tabular}

\section{Simpulan dan Saran}

Secara umum efektivitas aspek perencanaan manajemen prakerin di SMK Kota Yogyakarta mencapai kriteria "Sangat Efektif". Namun, secara khusus, hasil penelitian juga menunjukkan bahwa terdapat empat butir yang memiliki kesenjangan tinggi pada aspek ini. Keempat butir yang mengindikasikan adanya kendala ini terkait dengan jumlah pengurus pokja, relevansi antara DUDI dengan program keahlian SMK, kesepakatan antara DUDI dan sekolah, penempatan siswa, dan relevansi keahlian pembimbing dengan peserta prakerin.

Selanjutnya, efektifitas aspek pelaksanaan manajemen prakerin di SMK Kota Yogyakarta secara umum tercapai dengan kriteria "Sangat Efektif". Namun, seperti pada aspek sebelumnya, secara khusus pada aspek ini juga terdapat butir yang memiliki kesenjangan tinggi. Ada dua butir yang mengindikasikan adanya kendala pada aspek ini. Kedua butir itu terkait dengan pembekalan prakerin, dan waktu pelaksanaan prakerin. Kemudian pada efektivitas aspek evaluasi manajemen prakerin di SMK Kota Yogyakarta secara umum tercapai dengan kriteria "Sangat Efektif". Pada aspek ini tidak ditemukan adanya butir dengan kesenjangan tinggi.

Secara keseluruhan efektivitas manajemen prakerin di SMK Kota Yogyakarta memiliki rata-rata capaian $87 \%$ dengan kesenjangan (discrepancy) 13\%. Dengan rata-rata capaian tersebut maka manajemen prakerin di SMK Kota Yogyakarta termasuk "Sangat Efektif". Kemudian pada analisis kendala difokuskan pada butir yang memiliki kriteria dibawah "Cukup". Butir tersebut terdapat pada aspek perencanaan (butir 6, butir 15, butir 35, butir 39) dan pada aspek pelaksanaan (butir 49, butir 63), sementara pada aspek evaluasi tidak ada.

Hasil penelitian telah menunjukkan pencapaian masing-masing aspek dari manajemen prakerin di SMK Kota Yogyakarta. Melihat dari hasil penelitian tersebut, manajemen prakerin telah melaksanakan tugasnya dengan optimal. Hal tersebut perlu dipertahankan dan ditingkatkan oleh pokja. Salah satu cara meningkatkan kinerja adalah dengan mencari solusi terkait kendala yang terjadi. Berikut adalah saran atau rekomendasi yang dapat dipertimbangkan terkait hasil analisis kendala pada penelitian ini:

Dalam usaha pengembangan program prakerin sebaiknya selalu dilakukan evaluasi setiap akhir kegiatan. Hasil dari evaluasi kemudian digunakan oleh pokja sebagai bahan pertimbangan dalam menyusun program yang lebih baik. Pengembangan program juga membutuhkan SDM yang berkompetensi dan memiliki pengalaman yang mumpuni dalam dunia kerja dan industri. Apabila diperlukan, sekolah dapat menyusun kegiatan prakerin bagi guru. Hal tersebut diharapkan dapat meningkatkan pengetahuan guru terhadap kebutuhan kerja sehingga mereka dapat 
merancang program prakerin yang lebih baik dari sebelumnya.

Selanjutnya, analisis DUDI mitra tidak hanya dilakukan saat menjelang kegiatan prakerin, namun sebaiknya dilakukan lebih dini agar pokja memiliki lebih banyak waktu persiapan. Analisis juga bersifat terus-menerus, artinya pokja tidak hanya terpaku pada kebutuhan untuk mendapatkan DUDI mitra pada kegiatan prakerin saat itu saja. Pokja perlu membina hubungan baik dengan DUDI dan mengembangkan kerja sama antara keduanya. Pokja dapat melakukan pendekatan kepada pengusaha lokal agar dapat memperluas koneksi sehingga akan lebih mudah untuk melakukan kerjasama. Apabila dibutuhkan, sekolah dapat mengirim pokja untuk mengikuti pelatihan dalam usaha meningkatkan kemampuannya untuk mengelola kerjasama. Diharapkan dengan demikian kedepannya pokja tidak lagi mengalami hambatan dalam menyediakan tempat prakerin bagi siswa.

Supervising pokja perlu dilakukan baik oleh Kepala Sekolah langsung maupun menunjuk pihak lain untuk melaksanakan tugas tersebut. Hal ini dimaksudkan agar pokja selalu melaksanakan tupoksinya secara tepat. Sedangkan pada kendala kegiatan pembekalan, materi pembekalan dikembangkan setiap tahunnya dengan mempertimbangkan pengalaman pelaksanaan kegiatan prakerin sebelumnya. Lokasi pembekalan tidak harus di sekolah, pokja dapat berinovasi dengan memilih lokasi yang lebih menarik agar siswa lebih termotivasi dalam mengikuti kegiatan pembekalan. Terakhir, sekolah perlu melakukan pengembangan profesionalitas berupa seminar atau workshop kepada guru terkait pentingnya kegiatan prakerin bagi kemajuan sekolah dan siswa.

\section{Daftar Pustaka}

Arikunto, S \& Jabar, C.S.A. (2014). Evaluasi program pendidikan: Pedoman teoretis praktis bagi praktisi pendidikan. Jakarta: PT Bumi Aksara.
Alfeld, C. (2015). Building high-quality workbased learning programs for high school students. Louisville, KY: National Research Center for Career and Technical Education.

Boud, D \& Solomon, N. (2003). Work-based learning: A new higher education? Buckingham: SRHE and Open University Perss.

Certo, S.C \& Certo, S.T. (2012). Modern management: Concepts and skills. New Jersey: Pearson Education, Inc.

Clarke, L., \& Winch, C. (2007). Vocational education: International approaches, developments and systems. New York: Roulledge Taylor \& Francis Group.

Coombs, P.H. (1970). What is educational planning? [Versi elektronik]. Booklet of UNESCO: International Institute for Educational Planning.

Direktur Direktorat Pembinaan Sekolah Menengah Kejuruan. (2008). Pelaksanaan prakerin. Jakarta: DitPSM Kemendikbud.

Durlak, J. (2013). The importance of quality implementation for research, practice, and policy. Washington, DC: Department of Health \& Human Services.

Ellis, P. (2003). Arizona work-based learning resource guide: A guide for connecting career and technical education to the workplace. West Jefferson. Arizona Departement of Education, Career and Technical Education Division.

Fitzpatrick, J.L., Sanders, J.R, \& Worthen, B.R. (2011). Program evaluation: Alternative approaches and practical guidelines ( $\left.4^{\text {th }} \mathrm{ed}\right)$. New Jersey: Pearson Education, Inc.

Gasskov, V. (2000), Managing vocational training system:. A handbook for senior administrators. Geneva: International Labour Office.

Herlina, E. (2013). Efektivitas pengelolaan praktik kerja industri dalam rangka penyelenggaraan program 
pendidikan sistem ganda : Studi kasus tentang pengelolaan prakerin di SMK Negeri 1 Bandung. Tesis magister, tidak diterbitkan, Universitas Pendidikan Indonesia.

Hoeckel, K. (2008). Costs and benefits in vocational education and training. Paris: Organisation for Economic Co-operation and Development (OECD).

Holzer, H.J., \& Lerman, R.I,. (2014). Workbased learning to expand jobs and occupational qualifications for youth. Washington, DC: Center on Budget and Policy Priorities (CBPP).

Jahanian, R. (2012). Educational evaluation: functions and applications in educational contexts. International Journal of Academic Research in Economics and Management Sciences, Vol. 1, No. 2, 2226-3624.

Mardiningsih, L., \& Djukri, D. (2015). Upaya meningkatkan profesionalisme guru ipa smp di kecamatan sleman melalui optimalisasi kegiatan lesson study. Jurnal Akuntabilitas Manajemen Pendidikan, 3(2), 213-225. doi:http:/ / dx.doi.org/10.21831/am p.v3i2.6338

Sugiyono. (2014). Metode penelitian manajemen. Bandung: Alfabeta.

Sukarnati. (2011). Pengembangan model manajemen praktik kerja industri di sekolah menengah kejuruan. Disertasi Doktor, tidak diterbitkan, Universitas Negeri Yogyakarta.

Zomorrodian, A. (2011). New approach to strategic planning: The impact of leadership and culture on plan implantation via the three cs: cooperation, collaboration and coordination. Proceedings of ASBBS Annual Conference, Las Vegas, Vol. 18,No. 1, 1121-1132. 